\title{
WŁADCA BAŚNI. WOKÓŁ POLSKIEJ RECEPCJI CUDOWNEGO I POŻYTECZNEGO BRUNA BETTELHEIMA
}

\author{
Magdalena BednareK ${ }^{1}$ \\ (Uniwersytet im. Adama Mickiewicza w Poznaniu)
}

\begin{abstract}
Słowa kluczowe: baśnie, psychoanaliza, interpretacja, Bruno Bettelheim Key words: fairy-tale, psychoanalysis, interpretation, Bruno Bettelheim
\end{abstract}

\begin{abstract}
Abstrakt: Magdalena Bednarek, WŁADCA BAŚNI. WOKÓŁ POLSKIEJ RECEPCJI CUDOWNEGO I POŻYTECZNEGO BRUNA BETTELHEIMA. „PORÓWNANIA” 20, 2017. T. XX, S. 199-218. ISSN 1733-165X. Artykuł prezentuje polską recepcję wpływowej książki Bruna Bettelheima pt. Cudowne i pożyteczne, która ukazała się w USA w 1976 r., współtworząc tzw. renesans baśniowy, obejmujący zarówno badania akademickie, jak i twórczość artystyczną. Książka w polskim przekładzie Danuty Danek z 1985 r. odegrała (proporcjonalnie) jeszcze większą rolę na naszym rynku idei, inspirując nie tylko wielbicieli baśni, ich badaczy, literaturoznawców i humanistów w ogóle. Inspirująca lektura na przestrzeni 30 lat, które minęły od momentu ukazania się tłumaczenia, stała się jednak kanoniczna: choć przez pewien czas otwierała nowe horyzonty myślenia (nie tylko o baśniach), obecnie przyczynia się do ich zamykania. Artykuł omawia szereg kontrowersji i polemik, które na Zachodzie pojawiły się wokół pracy Bettelheima, w tekstach m.in.: Jacka Zipesa, Alana Dundesa, Pierre'a Péju, Jacqueline Rose, Marii Tatar, Ruth Bottigheimer. Być może przywołanie zastrzeżeń wobec Cudownego i pożytecznego przyczyni się do bardziej krytycznego odbioru tej książki w Polsce i sprawi, że na powrót stanie się ona zarzewiem dyskusji, a nie jej zwieńczeniem.
\end{abstract}

\begin{abstract}
Magdalena Bednarek, THE LORD OF THE FAIRY-TALE. THE POLISH RECEPTION OF THE USES OF ENCHANTMENT BY BRUNO BETTELHEIM. "PORÓWNANIA" 20, 2017. Vol. XX, P. 199-218. ISSN 1733-165X. The paper presents the Polish reception of The Uses of Enchantment by Bruno Bettelheim. The influential work published in 1976 in the U.S. was part of the fairy-tale renaissance, a movement which took place first place in Germany and then in North America within academic practises as well as in literature, movie art, photography, etc. Due to its unique position on the Polish market, Danuta Danek's translation of Bettelheim's monography had had an even greater impact on the local research not only in the field of the fairy-tales' interpretation,
\end{abstract}

1 E-mail: magbed@amu.edu.pl 
but in the humanities in general. In Poland in the last 30 years ideas from The Uses of Enchantment have been petrified, in spite of the fact that in the West Bettelheim's book was discussed and even attacked. The paper examines several controversies over the The Uses of Enchantment which have arisen in the Western humanities voiced by such authorities in the field as Jack Zipes, Alan Dundes, Pierre Péju, Jacqueline Rose, Maria Tatar and Ruth Bottigheimer.

Baśń jako szczególnie rozpowszechniona forma twórczości o długiej tradycji (sięgającej według jednych megalitu, antyku, według innych łacińskiego średniowiecza, zob. Zipes 2002: 7; Anderson 3-15; Ziolkowski 4-6), ciesząca się w związku z tym dużym uznaniem, niepozbawiona wartości estetycznych i moralnych, a przy tym podatna na ludyczne wykorzystanie, a także dająca znaczne możliwości oddziaływania społecznego, od XIX wieku znajduje się w obszarze zainteresowań badaczy. Pierwsza fala studiów przyniosła hipotezy o pochodzeniu baśni, a także funkcjonujące do dziś jako oryginalne, ludowe zbiory - m.in. braci Grimm, a w Polsce Oskara Kolberga. Wśród badaczy pierwszej połowy XX wieku szczególnie zasłużyli się Anttii Aarne (1911) oraz tłumacz na angielski i kontynuator jego pracy, Stith Thompson (1963) - twórcy indeksu obejmującego ponad 2,5 tysiąca wątków baśniowych, podzielonych na cztery grupy. Julian Krzyżanowski, uznając reprezentację tekstów słowiańskich w badaniach Aarnego i Thompsona za niewystarczającą, a ich katalog za niefunkcjonalny dla badaczy polskiego folkloru, w oparciu o polskie materiały etnograficzne stworzył Polska bajkę ludowa w układzie systematycznym (1947; 1963). Spory o klasyfikację poszczególnych wątków czy liczbę wydzielonych grup tekstów rozpalały wyobraźnię uczonych tamtych lat, prowadząc nie tylko do stworzenia systematycznych katalogów, ale również do zwiększenia świadomości uniwersalnego charakteru i wariantywności wątków. Należy jednak podkreślić, że równolegle w Związku Radzieckim Vladimir Propp tworzył fundamentalną dla późniejszych badaczy pracę o bajce w dwóch komplementarnych ujęciach: synchronicznym i diachronicznym, ukazując jej specyfikę jako formy w Morfologii bajki (1928) oraz jej kulturowe i religijne źródła w Historycznych korzeniach bajki magicznej (1946). Przełom lat 50. i 60. na Zachodzie został zdominowany przez spóźnioną recepcję formalistycznej analizy Proppa (1958) - paradoksalnie jednak przyniósł zainteresowanie narracyjnością, nie bajką magiczną.

Lata 70. oglądane z tej perspektywy można za Vanessą Joosen nazwać renesansem baśni (Joosen 4-6), wtedy bowiem ukazuje się szereg studiów (głównie anglo - i niemieckojęzycznych) rewidujących uznane tezy na temat naukowości metod zbierania tekstów folklorystycznych w XIX wieku, otwierających nurt badań nad socjalizującą funkcją baśni oraz studia nad nowożytnymi dziejami gatunku: wpływem wzrostu znaczenia mieszczaństwa jako klasy społecznej, przemian ekonomiczno-technologicznych, zależnością między rozwojem literatury pisanej i drukowanej a twórczością ludową i oralną, a także normatywizmem samych badań nad baśniami. W tamtej dekadzie ukazały się takie prace jak Fairy Tales Liberation Alison Lurie (1970), Some Day My Prince Will Come Marci K. Liberman (1972), Märchen, Phantasie 
und soziales Lernen Dietera Richtera i Johannesa Merkela (1974), Die älteste Märchensamlung der Brüder Grimm Heinza Röllekego (1975), Breaking the Magic Spell Jacka Zipesa (1979), a także The Uses of Enchantment Brunona Bettelheima (1976). Prace te łączy rewizjonistyczne zacięcie, prowadzące do demaskowania nieścisłości poprzednich badań oraz niejawnych, nieliterackich (klasowych, ekonomicznych, genderowych) mechanizmów kształtujących baśn jako gatunek, a także społecznych i psychologicznych aspektów poszczególnych wątków i motywów. Choć wszystkie wymienione książki wywarły wielki wpływ na badania nie tylko nad baśniami, ale także nad szeroką pojętą kulturą², w Polsce przez długi czas znana była (i szczególnie popularna) jedynie monografia Bettelheima, reprezentująca psychoanalityczną, freudowską perspektywę interpretacyjną.

Cudowne i pożyteczne. O znaczeniach $i$ wartościach baśni ukazało się w Polsce w 1985 roku w przekładzie Danuty Danek. Tłumaczka bardzo starannie opracowała tekst, uzupełniając go o szkic na temat genezy koncepcji i zainteresowań badacza, przedstawiając jego naukową biografię i omawiając najważniejsze tezy prac psychoanalitycznych, a także opatrując tłumaczony tekst szeregiem komentarzy, objaśniających skróty myślowe stosowane przez uczonego, przywołując szerszy kontekst jego teorii, wytykając niespójności interpretacji i przedstawiając własne propozycje rozumienia elementów baśni w paradygmacie psychoanalizy freudowsko-bettelheimowskiej. Staranna edycja sprzyjała popularyzacji książki; Cudowne i pożyteczne doczekało się w sumie trzech wydań (kolejne w 1996 i 2010), a wpływ interpretacji i założeń Bettelheima obserwować można na wielu płaszczyznach: naukowej, literackiej i plastycznej ${ }^{3}$.

Wiele tez uczonego na temat funkcjonowania baśni stało się niekwestionowanymi prawdami w polskim literaturoznawstwie: terapeutyczna funkcja baśni ${ }^{4}$ (zob. Bonowicz 149; Ciesielska 39; Lis-Kujawski 105; Gajownik 55; Sławińska 6; Baluch 95; Leszczyński 2006: 44, Karasińska 163; Wojciechowska 2003a: 115; Wojciechowska 2003b: 209-210; Karaś 198), przekonanie o tym, że ich interpretacje zaprezentowa-

2 Książka Liberman stała się jednym z kanonicznych feministycznych dzieł, refleksja Zipesa patronuje krytycznym, lewicowym analizom, praca Röllekego zapoczątkowała nurt krytycznych badań nad Grimmami.

3 Pojmowanie baśni jako eksternalizacji treści nieświadomych dostrzec można np. w cyklu fotografii Marii Dmitruk Baśnie (2003), seksualne odczytania folklorystycznych wątków są obecne w ilustracji do Śpiacej Królewny Anny Kunki-Kawełczyk (Cichocka, Miller); w literaturze w takich powieściach jak Siostra (2005) Małgorzaty Saramonowicz czy Królowa Tiramisu (2008) Bogdana Sławińskiego. Koncept terapeutycznego wykorzystania baśni natomiast widoczny jest we Wrońcu (2009) Jacka Dukaja. Wpływ książki Bettelheima na zachodnią twórczość artystyczną omówiła Vanessa Joosen (Joosen 129-184).

4 Ten aspekt teorii Bettelheima znajduje bardzo różnorodne formy wyrazu oraz rzeczowości i profesjonalizacji $\mathrm{w}$ polskich pracach: od przekonania o przydatności baśni $\mathrm{w}$ pracy (psycho)terapeutycznej z dziećmi po stwierdzenia o dużej ogólności na temat pociechy, jaką dziecko czerpie z obcowania z tym gatunkiem. Niektóre tezy Bettelheima o znaczeniu stricte psychoanalitycznym w niektórych pracach ulegają daleko idącej banalizacji (zob. Bonowicz 149). 
ne w Cudownym i pożytecznym mają swe źródła w praktyce psychoterapeutycznej uczonego (zob. Wais 24; Wojciechowska 2006b: 219), oraz wyższość baśni nad literaturą dziecięcą (zob. Ługowska 2006b: 50; Węgrodzka 312; Szabłowska-Zaremba 121; Skorupska-Raczyńska 85; Wlazło 316) i ich uniwersalizm (zob. Molicka 2006: 114; Ługowska 2006a: 8-9)5. Zaproponowana w Cudownym i pożytecznym metoda odczytywania fabuły i świata przedstawionego baśni jako eksternalizacji nieświadomych treści psychicznych dominuje (zob. Wojciechowska 2003a: 214; Knapek 2014: 326; Bogacka 343, 351; Bautsz-Sontag 176; Helman 110), a Bettelheimowskie interpretacje wątków i motywów baśniowych zyskały status kanonu lekturowego ${ }^{6}$. Ten kanoniczny status potwierdza praktyka omawiania współczesnych transformacji znanych baśni w odniesieniu nie tylko do wcześniejszych, folklorystycznych czy literackich wersji, ale także ich Bettelheimowskich wykładni (zob. Ługowska 2006b: 46-48, 171, 181; Wojciechowska 2003a: 136; Wais 77; Kwiek 133; Sadowska 261, 268; Serafin 273, 274; Lasoń-Kochańska 2012: 100). Można więc, podążając za interpretacyjnym rozumieniem kanonu zaproponowanym przez Andrzeja Skrendo, stwierdzić, że baśniowego kanonu nie tworzą takie baśnie jak Jaś i Małgosia, Czerwony Kapturek, Piękna i Bestia, Królewna Śnieżka, Przygody Sindbada Żeglarza, lecz Bettelheimowskie opowieści o nich (zob. Skrendo 65-74)7. Wpływ Cudownego i pożytecznego potwierdza zresztą explicite wielu badaczy, bezradnie wyznających swą niesamodzielność ${ }^{8}$ lub podkreślających doniosłość książki jako tekstu kultury in se.

Równocześnie nie można zapominać, że jakkolwiek książka Bettelheima była dziełem przełomowym $\mathrm{w}$ latach 70 . XX wieku, od tego czasu pojawiło się wiele krytycznych głosów na temat założeń i interpretacji obecnych w tej pracy - głosów,

5 Joosen wymienia trzy tezy obecne w Cudownym i pożytecznym, których obecność można wyśledzić w dyskursie akademickim i realizacjach plastycznych w świecie anglo-, niemiecko - i duńskojęzycznym: baśnie jako terapia, baśń jako drzwi do nieświadomości oraz reseksualizacja motywów baśniowych (Joosen 124-129, 167-169). Polska recepcja nieznacznie różniłaby się więc od zachodniej.

6 Baśnie takie jak Piękna i Bestia, Kopciuszek, cykl o narzeczonych zaklętych w zwierzę, Śpiąca Królewna, O Chłopcu, który nie wiedział co to strach, Braciszek $i$ siostrzyczka przywoływane są nieodłącznie z komentarzem uczonego. Jedyną konkurencyjną dla postfreudowskich interpretacji może być lektura w duchu psychologii głębi, którą reprezentują przekłady (zob. Jung; Estes; Bly; tutaj należy podkreślić, że wciąż na tłumaczenie czekają baśniowo-jungowskie książki Marie Louise von Franz) oraz oryginalne prace, często łączące oba podejścia psychoanalityczne (zob. Wais; Cichocka, Miller; Suchowierska, Eichelberger). Warto podkreślić jednak, że w pracach Bogusława Grodzkiego, a zwłaszcza Anny Czabanowskiej-Wróbel interpretacje Bettelheima rzadko są przywoływane jako mniej pomocne w badaniu materiału młodopolskiego (zob. Grodzki, Czabanowska-Wróbel).

7 Taką tezę potwierdzałaby edycja baśni adresowana do dzieci i rodziców wydawnictwa Prószyński i S-ka z 1999 roku, w której na kartach tytułowych i okładce przywołana została zarówno teoria baśni Bettelheima, jak i jego interpretacja poszczególnych wątków - te zostały odzwierciedlone także w ilustracjach do tekstu.

8 , $8[\ldots]$ moja próba psychologicznej eksplikacji tej baśni zdradza, jak bardzo jestem pod wpływem Bettelheima. Cóż - nie można nie czytać baśni Bettelheimem, jeśli się choć raz przeczytało Bettelheima” (Zgrzywa 202). „Interpretacja [Kopciuszka], którą właściwie można potraktować jako «sam w sobie» interesujący tekst kultury..." (Ługowska 2006b: 48; por. Pilińska 297). 
należy koniecznie dodać, niemal całkowicie ignorowanych w Polsce. Przez długi czas jedynie artykuł Justyny Deszcz (1998), prezentujący teorię amerykańskiego germanisty i znawcy baśni, Zipesa, uwzględniający także zarzuty tego uczonego względem Cudownego i pożytecznego, stanowił świadectwo bardziej zróżnicowanej, nie tylko aprobatywnej recepcji dzieła na Zachodzie ${ }^{9}$. Tekst ten nie wpłynął jednak znacząco na metodologię badań nad baśniami w Polsce: nie spopularyzował teorii Zipesa ani tym bardziej nie przyczynił się do krytycznego odbioru koncepcji Bettelheima.

Podobnie (znaczącego) wpływu nie miały zastrzeżenia Ryszarda Waksmunda, który zwrócił uwagę na nadreprezentację wątków o dziewczęcej inicjacji (Waksmund 2003: 73) ${ }^{10}$. Omawiając historię relacji między pedagogiką i baśniami, w sposób niewolny od sarkazmu zauważył, że podstawowe założenia pracy Bettelheima były obecne już w interpretacjach baśni z lat $20 .{ }^{11}$. Nie doprowadziło to jednak badacza do odrzucenia tej koncepcji, a do podkreślenia jej historycznej roli w procesie rehabilitacji gatunku (Waksmund 2000: 183), co wydaje się stanowiskiem ze wszech miar zrównoważonym.

Dopiero publikacja przekładu książki Péju Dziewczynka w baśniowym lesie. O poetykę baśni: w odpowiedzi na interpretacje psychoanalityczne i formalistyczne (1981, polski przekład 2008), który w poststrukturalistycznym duchu sprzeciwiał się, między innymi pragmatyzmowi, teleologiczności i uniwersalizmowi interpretacji Bettelheima, wpłynęła na polskie badania nad baśniami. „Chciałbym ocalić przed spustoszeniem, jakie czyni interpretacja [...], rozległe krainy świata baśni, aby na zawsze zachowały swe mroczne oblicze" (Péju 58) - przedstawiał cel swojej pracy francuski filozof. Jednak nawet w pracach uwzględniających jego zastrzeżenia (zob. Ćwiklak 11; Kostecka 72-73; zob. też Ratajczyk 129; Knapek 2012: 162; Filipowska 88, 91, 95), nie znajdują one odzwierciedlenia ani w metodologii badań, ani w kierunku interpretacji ${ }^{12}$. Sytuacja ta dowodzi, że kolejne przekłady klasycznych dzieł na omawiany temat prowadzić mogą do złamania psychoanalitycznego monopolu na baśnie i bardziej krytycznego wykorzystania koncepcji zaprezentowanych w Cudownym

9 Badaczka przypomniała konkluzję zarzutów Zipesa: „,[...] podejście psychoanalityczne musi przede wszystkim brać pod uwagę ludzi i ich społeczne zachowania, a dopiero potem ustalać psychologiczne znaczenia opowieści" (Deszcz 90).

10 Badaczki feministyczne z kolei sceptycznie odnosiły się do przekonania Bettelheima na temat uniwersalizmu dojrzewania, niezależności jego przebiegu od płci (Lasoń-Kochańska 2011: 15; Graban-Pomirska 105).

11 Np. rozumienie fabuły baśni w kontekście psychologicznych konfliktów w obrębie rodziny, przekonanie o możliwości terapeutycznego wykorzystania gatunku dzięki identyfikacji młodego odbiorcy z bohaterem oraz przeżywanie wraz z nim pozytywnego zakończenia (zob. Waksmund 2000: 175).

12 Nie można zbytnio przeceniać też recepcji książki Péju - jak na 10 lat obecności na polskim rynku książek i idei przywołanie jej w kilku pracach na temat baśni nie jest oszałamiającym sukcesem. Być może na niewielką znajomość książki Péju i jego krytyki Bettelheima (ale także Proppa) wpłynęły okoliczności wydawnicze. Książka ukazała się nakładem wydawnictwa Sic!, które publikuje głównie utwory beletrystyczne. 
i pożytecznym ${ }^{13}$. Nadreprezentacji Bettelheima towarzyszy bowiem brak przekładów nie tylko książek mu współczesnych, ale także powstałych w ostatnich 40 latach szczególnie dotkliwy wydaje się brak przekładów prac Zipesa, niekwestionowanego autorytetu, twórcy 15 książek o baśniowej tematyce, czy Cristiny Bacchilegii, badającej transformacje motywów baśniowych we współczesnej kulturze, oraz Mariny Warner, przedstawiającej historyczne i kulturowe funkcjonowanie gatunku.

Zanim (o ile) jednak doczekamy się przekładów wspomnianych tekstów, by móc korzystać z propozycji Bettelheima, konieczne jest przyjrzenie się zarzutom, z jakimi Cudowne i pożyteczne spotkało się w ciągu czterech dekad, które minęły od czasu pierwszego amerykańskiego wydania. Najpoważniejsze krytyczne głosy padły ze strony wspomnianego już literaturoznawcy, Zipesa (On the Use and Abuse of Folk and Fairy Tale with Children. Bruno Bettelheim's Moralistic Magic Wand, 1977 - artykuł opublikowany następnie w książce Breaking the Magic Spell z 1979) oraz „freudowskiego folklorysty", Alana Dundesa (The Psychoanalytic Study of Folklore, 1985, opublikowane później w książce Parsing Through Customs: Essays by a Freudian Folklorist, 1987), a także ze strony literaturoznawczyń wykorzystujących do interpretacji psychoanalizę freudowską - Jacqueline Rose (1984) - oraz lacanowską - Shuli Barzilai (1999) oraz germanistek - specjalizującej się w literaturze dziecięcej, Marii Tatar (1987), oraz znawczyni historii baśni, Ruth Bottigheimer (1989). Zgłoszone przez badaczy i badaczki zastrzeżenia można podzielić na metodologiczne i etyczne.

Duże wątpliwości budzi dobór baśniowych fabuł, które służą Bettelheimowi do zilustrowania swoich tez. Badacz wychodzi z założenia, że baśnie "przyjmują [...] psychoanalityczny model osobowości ludzkiej, kierując doniosłe przekazy do świadomej, przedświadomej i nieświadomej sfery umysłu, niezależnie od tego, na jakim poziomie każda $\mathrm{z}$ tych sfer $\mathrm{w}$ danym momencie funkcjonuje u konkretnego słuchacza" (Bettelheim 1: 43), i interpretuje fabuły najbardziej znane, np. o Jasiu i Małgosi, Czerwonym Kapturku, Kopciuszku, Królewnie Śnieżce, Śpiącej Królewnie, Jasiu-Jeżu czy Żabim Królu, przedstawiając w kolejnych rozdziałach książki, w jaki sposób symbolizują one podstawowe problemy psychologiczne: konieczność przedłożenia zasady rzeczywistości nad zasadę przyjemności, integracji wewnętrznej, przezwyciężenia konfliktów edypalnych oraz lęku przed płcią przeciwną. Bettelheim z wielowiekowej tradycji i dowiedzionego przez folklorystów rozpowszechnienia poszczególnych wątków baśniowych wywodzi wniosek o powszechności i uniwersalności konfliktów psychologicznych przedstawionych w baśniach, a także o społecznie akceptowanych sposobach radzenia sobie z nimi. Przy wyborze baśniowych przykładów deklaratywnie kieruje się ich po-

13 Do tej pory jedynie koncepcje Maxa Lüthiego były konsekwentnie popularyzowane (Lüthi 1972; Lüthi 1982a; 1982b; Kasjan 1994: 72-86). Wysiłki Jana Mirosława Kasjana zaowocowały pewnymi sukcesami - ukazała się monografia Lüthiego (Mojkowska), a jego tezy na temat baśni są przywoływane w pracach innych badaczy (zazwyczaj jako przeciwwaga wobec myśli formalistycznej, zob. Kostecka 66). 
pularnością, ostatecznie jednak analizuje niewiele, bo około 20 spośród ponad 400 wątków zaliczanych w folklorystyce do grupy bajek magicznych - trudno więc uznać, że pozwala to na wyciągnięcie wniosków o uniwersalności i powszechności odnajdywanych w nich konfliktów psychologicznych, co zauważają Tatar oraz Dundes (zob. Tatar 1987: 43; Dundes 1987: 30). Z drugiej strony niektóre tezy (np. o konieczności życia zgodnie z wymaganiami superego) najdobitniej ilustrują według badacza baśnie, które, jak sam zauważył, nie znajdują się we współczesnym baśniowym kanonie (jak np. Królowa pszczót). Stosując tok rozumowania Bettelheima należałoby więc raczej uznać na tej podstawie, że ten problem być może był niegdyś istotny (skoro baśń funkcjonowała w folklorystycznym obiegu), jednak obecnie stracił na znaczeniu lub powszechności.

Z drugiej strony można przypomnieć zarzuty Zipesa oraz Péju, którzy zauważyli, że rodzina, w której rodzi się większość problemów psychologicznych omawianych przez Bettelheima, jest zjawiskiem społecznym dużo późniejszym niż baśnie, w których uczony dopatruje się ich odzwierciedlenia (zob. Péju 62-64). Z tej perspektywy jego interpretacje byłyby pozbawione walorów historycznych. W tym kontekście Zipes przeciwstawia uniwersalistycznemu i ponadczasowemu podejściu Bettelheima Freudowskie uprzywilejowanie socjokulturowej genezy zjawisk psychicznych (zob. Zipes 2002: 185-186). Należy też podkreślić, że zarówno Péju, jak i Zipes zwracają uwagę na społeczno-psychologiczny normatywizm Bettelheima, który zakłada, że problemy psychologiczne wymagają konkretnego podejścia, jeśli mają zostać przezwyciężone, przez co sankcjonuje represyjność rodziny i społeczeństwa: „Zajmując takie stanowisko, Bettelheim bezwiednie staje się apologetą «cywilizowanego społeczeństwa», które raczej trzeba by oskarżyć o stosowanie przemocy względem dzieci i tendencje dehumanizacyjne" (Zipes 2002: 188; por. Zipes 2002: 186-190; Péju 83-85). Wyraziście widać to w interpretacji Brzydkiego kaczatka Hansa Christiana Andersena (zob. Bettelheim 1: 201-202), które ma być opowieścią eskapistyczną, niezachęcającą dziecka do zajęcia aktywnej postawy względem problemu. Cudowną przemianę Bettelheim zdecydował się jednak, tendencyjnie, odczytywać dosłownie, a przecież można ją rozumieć właśnie jako powolny, niezakłócony i niewymuszony przez społeczeństwo („na wygnaniu”) samoczynny rozwój, samodoskonalenie się. Przemiana zachodziłaby tyleż w bohaterze, co w oczach osądzających go (por. Zipes 2005: 55-60).

Szczególny przypadek aprobowanego normatywizmu stanowi genderowe zróżnicowanie baśni w Cudownym i pożytecznym. Jakkolwiek Bettleheim początkowo stawia tezę, że baśnie przemawiają do chłopców i dziewcząt niezależnie od płci protagonisty (zob. Bettelheim 1: 61), to dalej jednak zauważa, że identyfikacja z bohaterem przeciwnej płci jest trudniejsza i bardziej pracochłonna (zob. Bettelheim 1: 125), a w samych interpretacjach niejednokrotnie pewne problemy uznaje za typowo dziewczęce: całkowicie pominięcie w części interpretacyjnej baśni o kobietach zaklętych w zwierzę prowadzić może do wniosku, że chłopcy nie odczuwają lęku 
przed seksualnością kobiet (zob. Bettelheim 2: 201-253). O fallocentryzm explicite oskarża Bettelheima Péju (zob. Péju 85).

Trudno z kolei zgodzić się z zarzutem Zipesa, że jako cel opowiadania baśni uczony przedstawia oswojenie treści nieświadomych, co doprowadzić ma do stworzenia spójnej tożsamości (zob. Zipes 2002: 184-187). Bettelheim wprost stwierdził, że dziecko porzuca baśń, gdy przestaje odpowiadać jego problemom, i zwraca się ku następnej, w której odnajduje symbol aktualnie przeżywanych konfliktów - proces poszukiwania adekwatnych narracji nigdy się nie kończy (zob. Bettelheim 1: 63).

Badacz przeciwstawia baśń literaturze dziecięcej i dokonuje swoistej apoteozy gatunku, dowodząc że „[...] jest to jedyny wytwór sztuki tak całkowicie zrozumiały dla dziecka", a także, w przeciwieństwie do literatury specjalnie dla dzieci pisanej, wieloznaczny: „Dziecko wydobędzie rozmaite znaczenia z tej samej baśni zależnie od swoich zainteresowań i potrzeb w konkretnej fazie rozwoju" (Bettelheim 1: 53). Przyczyną takiej mocy oddziaływania ma być artystyczna wartość tekstu: „Oczarowanie, jakiego doznajemy, gdy poddajemy się oddziaływaniu baśni, nie wywołują jej psychologiczne treści (choć one również do tego się przyczyniają), ale jej wartości literackie: wywołuje je baśń jako dzieło sztuki" (Bettelheim 1: 53). $Z$ tego też względu, choć uczony przywołuje aranżacje wątków folklorystycznych Basilego, Perraulta, pani de Beaumont czy baśnie Andersena, zdecydowanie uprzywilejowuje te braci Grimm, widząc w nich najczystsze reprezentacje folklorystycznych wątków. Baśnie Perraulta czy Basilego, choć wcześniejsze od niemieckich, marginalizuje, co musi budzić gorący sprzeciw z przynajmniej kilku powodów. Przede wszystkim Bettelheim krytykuje, wbrew wcześniejszym deklaracjom o doniosłości estetycznej baśni, te aspekty tekstów włoskich i francuskich, w których najbardziej wyeksponowana jest ich literackość, np. elementy intertekstualne u Basilego, stosowanie różnych form podawczych przez Perraulta; inne swoiście literackie tropy, jak zauważyła Danek w komentarzach do przekładu, pozostają dla Bettelheima niezauważalne, np. ironia w Bajkach babci gąski, którą badacz naiwnie odczytuje jako moralizatorstwo (zob. Bettelheim 2: 239, 242). Absolutyzując jedną historyczną postać bajki magicznej, ukształtowaną w XIX wieku, zdradza tym samym, że obce jest mu myślenie w kategoriach historycznych: a przecież motywy baśniowe zyskały pierwszą, wyrazistą gatunkową postać na przełomie XVI i XVII wieku; określała ją kunsztowna kompozycja szkatułkowa, odniesienia intertekstualne i aluzje do mieszczańskiej egzystencji (zob. Jolles 70-71; Bottigheimer 2009: 10-22). Francuski XVIII-wieczny etap rozwoju gatunku obejmował natomiast eksponowaną metaliterackość, intertekstualność, utopijność oraz aluzje do transformacji społeczeństwa i absolutystycznej władzy - a same baśnie funkcjonowały już to jako utwory rozbudowane do wielkości mikropowieści, już to jako opowieści wtrącone w obrębie innych utworów narracyjnych (zob. Zipes 2007: 33-52). Współczesne aranżacje folklorystycznych wątków, także te adresowane do dzieci, pełne są elementów metaliterackich, gier intertekstualnych odnoszących się do tradycji 
baśniowych i nie tylko, ponadto nie są wolne od ironii (Kostecka 161-220). Dziwić musi też niekonsekwencja Bettelheima, który dopatrzywszy się u Perraulta morału, uznał go za dowód zmanierowania i przyczynę terapeutycznej bezwartościowości, jako wzorcową wersję Pięknej $i$ Bestii przedstawił natomiast tę pani de Beaumont (zob. Bettelheim 2: 241-242; 244-253): skrajnie dydaktyczną opowiastkę dla dzieci, reprezentującą konserwatywną ideologię, jak dowiodły historyczne analizy Zipesa (zob. Zipes 1994: 32-41).

Negatywnie postrzeganą tradycję Bettelheim kontrastuje z baśniami braci Grimm, które służą mu za wzorzec baśni w ogóle, ponieważ pełnić mogą funkcje terapeutyczne. Jest to możliwe dzięki pojawieniu się słabo scharakteryzowanego, typowego bohatera, który najczęściej funkcjonuje pod ogólnym lub symbolicznym mianem, schematyzacji fabuły (w tym szczęśliwemu zakończeniu) i jednoznaczności aksjologicznej świata przedstawionego (zob. Bettelheim 1: 47-48). Ta, co należy podkreślić, historyczna postać bajki magicznej, zyskała popularność m.in. dzięki zbiorowi braci Grimm, którzy jednak wcale nie byli, jak chce to widzieć Bettelheim, jedynie zbieraczami ludowych narracji, a współtwórcami tej postaci gatunku. Rölleke oraz Richter i Merkel w książkach opublikowanych w pierwszej połowie lat 70. i dyskutowanych w Stanach Zjednoczonych przedstawili wyniki badań nad dotychczas niekwestionowaną tożsamością informatorek i informatorów Grimmów, dowodząc ich francuskich i mieszczańskich korzeni, a także porównując rękopisy i kolejne wersje Baśni z finalnym wydaniem z 1857 roku. Udowodnili oni, że Grimmowie konsekwentnie modelowali usłyszane teksty, dokonując wyborów stylistycznych, manipulując konstrukcją świata przedstawionego oraz przebiegiem fabuły, co doprowadziło do powstania gatunku Grimmów, formy łączącej elementy folklorystyczne i literackie (Gattung Grimm, zob. Tatar 1987: 33; por. Jolles 66). Zignorowanie tych odkryć przez Bettelheima jego krytycy podnoszą jako zarzut nieuwzględnienia współczesnego stanu wiedzy o baśniach (zob. Dundes 1991: 76). Prowadzi to Bettelheima do interpretowania w kategoriach psychologicznego uniwersalizmu rozwiązań stricte biedermeierowskich. I tak baśniowe macochy słusznie utożsamia Bettelheim z matkami, jednak interpretuje rozszczepienie postaci macierzyńskiej na aspekt pozytywny i negatywny jako eksternalizację mechanizmu obronnego dziecka, które nie jest w stanie zaakceptować wymagań, jakie zaczyna mu stawiać rodzic. Jednak rękopisy Grimmów dowodzą, że usłyszane przez nich baśnie były pozbawione tego rozszczepienia: to matka wygnała Jasia i Małgosię i matka pragnęła śmierci Królewny Śnieżki. Badacze interpretują zmianę dokonaną przez Grimmów w kontekście kształtującej się od XVIII wieku w klasie średniej roli matki, ze względu na którą niemożliwa była do zaakceptowania macierzyńska postać działająca na szkodę dzieci (zob. Tatar 1987: 37; Dundes 1991: 78-79). Podobnie Bettelheim jako omyłkę psychoanalityczną, zdradzającą nieświadomą chęć wyzbycia się sekretu przed matką, interpretuje słowa Roszponki o różnicy w ciężarze między czarownicą a księciem. Autorami tej omyłki są jednak Grimmowie, 
którzy oczyszczali usłyszane baśnie z elementów obyczajowo kontrowersyjnych we wcześniejszej wersji dziewczyna zwraca uwagę, że jej ubrania przestały na nią pasować w środkowej części ciała (zob. Zipes 2007: 75-78; Tatar 1987: 18-19). Z tej perspektywy należałoby zapewne zmodyfikować tezę Bettelheima, że baśń ta pozwala dziecku postrzegać swoje ciało jako źródło mocy i wybawienia (Roszponka znajduje szczęście w ramionach księcia dzięki włosom, uzdrawia go zaś swoimi łzami) (zob. Bettelheim 1: 274), i dodać, że bywa ono także zdrajcą, źródłem nieszczęścia i braku akceptacji. Bettelheimowi zarzucić można chyba jednak nie nieznajomość współczesnych mu badań folklorystycznych, a ich swobodne wykorzystanie: jeśli pasuje to do celów interpretacyjnych, uwzględnia rękopiśmienne wersje baśni Grimmów. Tak dzieje się, gdy interpretuje Żabiego Króla jako wyraz lęku dziewczyny przed męską seksualnością, którą przezwyciężyć może tylko bezpośrednia konfrontacja, pozwalająca zobaczyć w obrzydliwym stworzeniu pięknego młodzieńca. W kanonicznej wersji ta transformacja dokonuje się za sprawą pocałunku, Bettelheim jednak przywołuje na potwierdzenie swojej tezy o wadze inicjacji seksualnej dla przezwyciężenia lęku przed płcią przeciwną wersję, w której żaba zamienia się w królewicza po pokładzinach (zob. Bettelheim 2: 218).

Tutaj trzeba także dodać, że Bettelheim, korzystając z przekładów analizowanych baśni, nie zawsze konfrontował je z oryginałami lub tłumaczeniem literalnym. W przypadku Księgi tysiąca i jednej nocy oparł się na angielskim przekładzie Richarda Burtona z 1885 r. i na tej podstawie interpretował opowieść o Sindbadzie Tragarzu i Sindbadzie Żeglarzu, dochodząc do wniosku, że "gdyby to była baśń z kręgu kultury zachodniej, kończyłaby się zapewnieniem, że obaj żyli odtąd razem długo i szczęśliwie" (Bettelheim 1: 171), co lepiej eksponowałoby jego tezę, że postaci te stanowią eksternalizację dwóch aspektów psychiki - ego i id, które muszą się zintegrować, jeśli jednostka ma uzyskać równowagę wewnętrzną. Szkopuł w tym, że, jak zauważyła Danek, baśń arabska pod tym względem wcale nie ustępuje głębią analizy psychologicznej przywoływanym wcześniej baśniom europejskim (Trzy małe świnki) - i oczekiwane przez Bettelheima zakończenie się w niej pojawia. Jedynie XIX-wieczny tłumacz na język angielski go nie uwzględnił.

Niewielka liczba omawianych wątków i sprzeczne kryteria wartościowania tekstów łączą się także z samym kierunkiem interpretacji zaproponowanym w Cudownym i pożytecznym; w większości analizowanych baśni uczony dopatruje się bowiem symboliki erotycznej, co prowokuje najzagorzalszych krytyków do niepozbawionych złośliwości konstatacji, np. Ruth Bottigheimer stwierdziła, że Bettelheim „[...] jest skory, by widzieć fallusa we wszystkim, co jest dłuższe niż szersze, a w każdej głębi dostrzegać waginę" (cyt za: Joosen 187; por. Zipes 2002: 191; Péju 58-59). Zipes z kolei krytykuje nie tyle odczytanie poszczególnych elementów, co zawsze tam sam cel, do którego zmierzają interpretacje uczonego: „W zasadzie którejkolwiek opowieści nie tknie ortodoksyjnie Freudowska różdżka Bettelheima, zawsze zamienia się ona w symboliczną parabolę o samorealizacji i zdrowej seksualności" 
(Zipes 2002: 192). Oczywiście można dość łatwo odeprzeć te zarzuty, wskazując, że są one czynione z zewnątrz - wynikają z zanegowania wartości psychoanalitycznej interpretacji; niektóre głosy wskazują jednak na znaczące zmiany w sposobie rozumienia teorii Freuda. Najbardziej problematyczna wydaje się jednoznaczna interpretacja baśniowych znaków: Péju zwrócił także uwagę, że w przeciwieństwie do Freuda, Bettelheim skłonny jest widzieć w różnych elementach baśni konkretne, często powtarzające się znaczenia, nie zważając na odmienny kontekst, w którym się one pojawiają (zob. Péju 72-73). Dalej Péju uznał, że autor Cudownego i pożytecznego absolutyzuje pojęcia, które od narodzin psychoanalizy budziły wątpliwości, takie jak kompleks Edypa u dziewcząt, czy fazę utajenia (zob. Péju 72-73); Zipes z kolei zwrócił uwagę, że Freud postrzegał rodzinę jako pośrednika między jednostką a społeczeństwem, podczas gdy u jego ucznia urasta ona do rangi autonomicznego bytu, wspierającego rozwój jednostki (zob. Zipes 2002: 186).

Porzucając jednak zastrzeżenia wobec freudyzmu Bettelheima i psychoanalitycznej interpretacji, trzeba przypomnieć najmocniejszy zarzut, jaki stawia mu Péju: redukcjonizm interpretacyjny uczonego prowadzić ma do racjonalizacji baśni; w miejsce cudowności pojawia się tajemnica, którą należy wyjaśnić: „podejście psychoanalityczne do baśni zanurza nas w pewnego rodzaju rodzinnej powieści policyjnej albo raczej policyjnej powieści rodzinnej, a inspektor Bruno, pomiędzy jednym a drugim pyknięciem fajki, podaje klucz do zagadki" (Péju 71).

Terapeutyczne zastosowanie baśni, kolejna główna teza obecna w Cudownym i pożytecznym, także spotkała się z krytyką. Bettelheim przedstawił swoje interpretacje oraz przekonanie o terapeutycznej funkcji obcowania z baśniami przede wszystkim jako wynik pracy z pacjentami ze Szkoły Ortogenicznej, której był długoletnim dyrektorem, ale także rodzicielskiego doświadczenia. Jednak dokumentacja praktyki Bettelheima rzuca cień na hipotezę o takiej genezie jego interpretacji, ponieważ istnieją ślady niszczenia zapisów z sesji nie wspierających interpretacji uczonego oraz nie ma potwierdzeń skuteczności opowiadania baśni jako metody terapii (zob. Joosen 185-186). Także dzieci uczonego nie potwierdzają, by ojciec czytywał im baśnie (zob. Zipes 2002: 180). Jakkolwiek te argumenty nie przekreślają interpretacji Bettelheima, to z pewnością zmieniają ich usytuowanie - z przestrzeni doświadczalnie potwierdzonych interpersonalnych znaczeń przenoszą je do literaturoznawczych propozycji, których poprawności i prawomocności nie weryfikuje żadne zewnętrzne kryterium. Tłumaczyłoby to także, dlaczego współczesna bajkoterapia tak bardzo odbiega od Bettelheimowskich założeń (zob. Molicka 2011: 213-246.).

Zipes kwestionuje tezę Bettelheima o terapeutycznej wyższości baśni nad innymi tekstami, punktując, że uczony w żaden sposób jej nie udokumentował, nie posiadał także wiedzy o literaturze dziecięcej oraz sposobach jej oddziaływania na młodego odbiorcę (zob. Zipes 2002: 183). W sarkastyczny sposób krytykuje pragmatyczne wykorzystanie baśni: „Po lekturze wniosków Bettelheima można się zastanawiać, czemu w ogóle służą takie książki np. Dale’a Carnagiego Jak zdobywać 
przyjaciót $i$ wptywać na ludzi czy Jak osiagnać sukces w biznesie, skoro mamy baśnie" (zob. Zipes 2002: 193-194). Pragmatyzm uczonego z innej perspektywy negatywnie ocenia również Péju, zwracając uwagę, że baśnie pełne są nieakceptowanych społecznie pożądań, które nie spotykają się z karą, stąd wniosek, że tego typu utwory bywają całkowicie pozbawione moralistycznego czy socjalizującego wymiaru (zob. Péju 84-91).

Można także zwrócić uwagę, że pierwsze utwory baśniowe z myślą o dziecięcym odbiorcy powstały dopiero $\mathrm{w}$ połowie XVIII w. (zaś w połowie XIX wieku młode osoby stały się znaczącą grupą odbiorców takich utworów), wcześniej był on przypadkowym słuchaczem historii opowiadanych dorosłym przez dorosłych (zob. Zipes 2006: 98-99; por. Propp 76-86), co zresztą znajduje odzwierciedlenie w tytule najsłynniejszego tomu baśni - Grimmów: Baśnie dla dzieci i domu (por. Pieciul-Karmińska 480-483). Z tego też względu doszukiwanie się w tradycyjnych wątkach opowieści o dziecięcych problemach wydaje się mocno wątpliwe. Rose idzie w swym sceptycyzmie zdecydowanie dalej, uznaje bowiem, że literatura adresowana do dzieci odzwierciedla w rzeczywistości pragnienia dorosłych (zob. Rose).

Moralne zarzuty formułowane wobec Bettelheima w związku z Cudownym i pożytecznym dotyczą trzech aspektów jego pracy: postulowanego sposobu wykorzystania baśni względem dziecięcych odbiorców, sposobu przedstawienia seksualności dzieci oraz oryginalności jego pracy ${ }^{14}$.

Bettelheim podkreślał, że terapeutyczne oddziaływanie opowieści jest możliwe tylko wtedy, jeśli dziecko nie wie, dlaczego jakaś baśń budzi jego zainteresowanie. Wówczas treści nieświadome, popędy niezyskujące aprobaty społecznej mogą zostać oswojone, podczas gdy uświadomienie ich młodemu słuchaczowi wywołałoby w nim poczucie winy i niższości wobec rodziców, którzy okazują się znać jego myśli lepiej niż on sam (zob. Bettelheim 1: 121-122). Dundes przypomina jednak w tym kontekście Freudowskie założenia dotyczące psychoanalizy, która, jeśli ma przynieść pozytywne skutki, musi być dobrowolna i świadoma (zob. Dundes 1987: 30). $Z$ tego punktu widzenia propozycja Bettelheima jawi się Dundesowi jako nieetyczna, czyni bowiem dziecko całkowicie bezbronnym wobec działań dorosłego. Jakkolwiek trudno nie zgodzić się z zarzutami Dundesa w kontekście analizy klinicznej, nie można zapominać o tym, co autor Cudownego i pożytecznego podkreślał w zakończeniu swojej książki: powstała ona, by rodzice lepiej rozumieli swoje dzieci i problemy, z jakimi one się mierzą, a nie jako podręcznik dla psychoanalityków (zob. Bettelheim 2: 253-254; por. Dundes 1991: 75). W myśl założeń Bettelheima rodzice mają raczej podążać za baśniowymi fascynacjami dziecka, by wiedzieć, z jakimi problemami się ono aktualnie boryka, i towarzyszyć mu w tych zmaganiach,

14 Na początku lat 90. pojawiły się także pod adresem Bettelheima oskarżenia o stosowanie przemocy wobec podopiecznych ze Szkoły Ortogenicznej. W pełnym emocji artykule polemizowała z nimi Danek (Danek 1997: 455-483). 
okazując akceptację dla projekcji, których w trakcie dokonuje odbiorca, niż proponować jakieś opowieści w celu rozładowania konfliktów psychicznych (zob. Bettelheim 1: 231-233) ${ }^{15}$. Szczególnie trafne jest spostrzeżenie Tatar, że w myśl koncepcji Bettelheima opowiadanie baśni jest okazją do przekazywania pewnych treści, a nie przestrzenią wymiany i dialogu (zob. Tatar 2009: 86).

Badaczka zwróciła uwagę, że Bettelheim o niewłaściwie ukierunkowane pożądanie zawsze posądza dzieci (zob. Tatar 1987: 161; por. Barzilai 212-213). Najbardziej jaskrawym przykładem absolutyzacji kompleksu Edypa jest interpretacja egipskiej baśni o dwu braciach. Do jednego z jej epizodów, próby uwiedzenia młodego chłopca przez dojrzałą szwagierkę, nawiązuje biblijna historia Józefa i Pazyfae. Ten właśnie wątek Bettelheim proponuje odczytywać jako projekcję edypalnych pragnień młodzieńca wobec macierzyńskiej postaci (zob. Bettelheim 1: 184).

Zastrzeżenia dotyczące oryginalności pracy Bettelheima sformułował Dundes. Omówiwszy nieodnotowywanie przez Bettelheima zależności od wcześniejszych prac psychoanalitycznych na temat baśni, przypomniał zarzuty, jakie pod adresem uczonego padły w 1978 r., i przytoczył szereg kolejnych wypisów potwierdzających zbieżności między Cudownum i pożytecznym i A Psychiatric Study of Myths and Fairy Tales Juliusa Heuschera (1963) (a także pracami Otto Ranka, Gézy Róheima oraz samego Dundesa; zob. Dundes 1991: 79-81), konkludując: „Niezależnie czy jest to konsekwencja lenistwa czy otwartej nieuczciwości intelektualnej, osobisty i wart zauważenia wkład Bettelheima w Cudownym i pożytecznym jest trwale zszargany przez jego porażkę w przestrzeganiu konwencjonalnej akademickiej etykiety" (Dundes 1991: 81). Heuscher, najbardziej poszkodowany w oczach Dundesa, nie odbiera tego w taki sposób i zwraca uwagę na powszechność niektórych idei w humanistyce (zob. Stein).

$* * *$

Przedstawione zarzuty w żaden sposób nie wpłynęły na recepcję książki Bettelheima $w$ Polsce. Uprzywilejowanie jego interpretacji w pracach polskich badaczy oraz, choć w mniejszym stopniu, artystów można by postrzegać jako zbieg okoliczności, przypadek, a może po prostu znak rozpoznania w tej metodzie najbardziej efektywnego i interesującego sposobu lektury. Jednak z perspektywy nieobecnej (czy incydentalnie przywoływanej) alternatywy wybór ten jawi się jako forma konserwatyzmu - ucieczki od historycznych, geopolitycznych, genderowych, klasowych, ekonomicznych uwarunkowań baśni i jej rozumienia w krainę uniwersali-

15 Oczywiście można postawić pytanie, na ile będzie to pewna wiedza i wspomagająca asysta, jeśli to laik ma posługiwać się kategoriami psychoanalitycznymi (choćby w celach ogólnodiagnostycznych), a w każdej baśni, zależnie od fazy rozwoju psychoseksualnego, dziecko może być zaintrygowane innym jej aspektem - a więc nadawać jej różne znaczenia (zob. Bettelheim 1: 53). 
zmu i ponadczasowości konfliktów psychologicznych. Zachowawczość tę można także postrzegać na płaszczyźnie metodologicznej jako ucieczkę od teorii i interpretacji słabo lub w ogóle niespopularyzowanych przekładami ${ }^{16} \mathrm{i}$ jednostkowo obecnch $\mathrm{w}$ polskich badaniach i pracach ku dobrze znanym, cenionym i już popularnym.

Konserwatyzm ten wydaje się niebezpieczny dla samych baśni. Metodologiczna i interpretacyjna propozycja Bettelheima zaprezentowana w Cudownym i pożytecznym stanowi przejaw zawładnięcia literaturą przez dyskurs. Teoretycznie w definicji baśni Bettelheim odwołuje się do kategorii literaturoznawczych, pisząc o typowości bohatera, ogólności przedstawionych sytuacji, czarno-białym obrazie rzeczywistości, fabule prowadzącej do szczęśliwego zakończenia. Tak opisany gatunek wydaje się więc formą prostą i inkluzywną (przez małą liczbę wyznaczników i ograniczenie ich tylko do konstrukcji świata przedstawionego i fabuły), uniwersalną i ponadczasową; jednak jak dowodzą z jednej strony same interpretacje Bettelheima, z drugiej - historia literatury, tak nie jest. Uczony, opierając swoje przekonania na temat konstrukcji baśni na bardzo wąskiej grupie tekstów ukształtowanych w konkretnym czasie i miejscu, absolutyzuje wnioski (w tym sensie też zbliża się do rozumienia baśni jako prostej formy w znaczeniu Jollesa, zob. Jolles 65-84). Co więcej, charakteryzuje baśń przez pryzmat tych elementów poetyki, które czynią analizowane utwory poręcznymi dla zaprojektowanych dla nich celów. Każda z wymienionych właściwości podporządkowana jest konkretnej funkcji, jaką ma spełniać: dziecięcy odbiorca ma się łatwo utożsamić $\mathrm{z}$ niezindywidualizowanym bohaterem; $\mathrm{w}$ ledwie zarysowanym świecie przedstawionym rozpoznać, przeczuć eksternalizację swoich problemów; jednoznaczna aksjologia ma służyć wskazaniu, które postawy są społecznie aprobowane, a szczęśliwe zakończenie ma natchnąć go wiarą w możliwość pozytywnej zmiany własnej sytuacji. Tych utworów, które w niedostatecznym stopniu odzwierciedlają konstrukcję psychiczną jednostki i problemy, z jakimi ona się zmaga, lub są pozbawione wzorców ich przezwyciężenia - a co za tym idzie są bezużyteczne terapeutycznie - nie uznaje się za reprezentatywne dla gatunku. Zgodnie z taką logiką Bettelheim wyklucza teksty Andersena, ale akceptuje Stońce, Księżyc i Talię Basilego albo Piękną i Bestię pani de Beaumont (także baśni literackie), ponieważ pozwalają mu dowieść tezy o paralelności jednostkowej nieświadomości uzewnętrzniającej się w snach - i baśniach. Baśń więc musi być formą prostą, by móc unieść ciężar interpretacji, szczegóły mogłyby sprawić, że widoczna byłaby niezgodność między utworem, a narzucającym mu znaczenia dyskursem.

O gatunkowości decydować mają zatem $\mathrm{w}$ istocie nie właściwości literackie, a pragmatyczne, (psycho)terapeutyczne zastosowanie tekstu, co bardzo dobrze widać w interpretacji Złotowłosej, będącej według Bettelheima baśnią nieudaną, bo nieoferującą odbiorcy wizji osiągniętej dojrzałości i harmonijnego egzystowania

16 Obecność tłumaczeń nie jest jednak chyba czynnikiem decydującym, czego dowodzą feministyczne, artystyczne próby reinterpretacji baśni (w plastyce i literaturze). 
w rodzinie (zob. Péju 80-81), a co za tym idzie - nieprzydatną w terapii (zob. Bettelheim 2: 111-112). Baśń wydawać się więc może nasycona bogactwem nowych, poważnych, psychoanalitycznych znaczeń i społecznej przydatności, odświeżona, cenniejsza, mądrzejsza - atrakcyjniejsza. Traci jednak w takiej perspektywie swoją autoteliczność, wieloznaczność i niepowtarzalność: zamienia się w masowo reprodukowany wytwór (dyskursu).

\section{BIBLIOGRAFIA}

Anderson, Graham. Fairy Tales in the Ancient World. Londyn, Nowy Jork: Routledge, 2003.

Baluch, Alicja. „Odsłonić to, co ukryte, czyli od myszki do Myszki w różnych odmianach literatury fantastycznej. Kulturowe konteksty baśni. T. 1. Rozigrana córa mitu. Red. G. Leszczyński. Poznań: Centrum Sztuki Dziecka, 2005. S. 94-100.

Barzilai, Shuli. Lacan and the Matter of Origins. Stanford: Stanford University Press, 1999.

Bautsz-Sontag, Anna. „Symbole baśniowe - metafora doświadczeń intrapersonalnych dzieci. Baśń we wspótczesnej kulturze. T. 2. Królestwo człowiecze: edukacja-psychoanaliza-arteterapia. Red. K. Ćwiklak. Poznań: Wydawnictwo UAM, 2015. S. 175-194.

Bettelheim, Bruno. Cudowne i pożyteczne: o znaczeniach i wartościach baśni. Przeł. Danuta Danek. T. 1-2. Warszawa: PIW, 1985.

Bly, Robert. Żelazny Jan: rzecz o mężczyznach. Przeł. Jan Tittenbrun. Poznań: Dom Wydawniczy Rebis, 1993.

Bogacka, Katarzyna. „Analiza ikonograficzno-psychonalityczna ilustracji Franza Jüttnera do baśni Królewna Śnieżka (Schneewittchen) braci Grimm”. Baśń we wspótczesnej kulturze. T. 1. Niewyczerpana moc baśni: literatura - sztuka - kultura masowa. Red. K. Ćwiklak. Poznań: Wydawnictwo UAM, 2014. S. 333-354.

Bonowicz, Karina. „Dlaczego wilk ma wielkie oczy? - psychoanalityczna interpretacja tzw. Baśni inicjacyjnej na przykładzie Czerwonego Kapturka i Żelaznego Jana". Baśń we współczesnej kulturze. T. 2. Królestwo człowiecze: edukacja - psychoanaliza - arteterapia. Red. K. Ćwiklak. Poznań: Wydawnictwo UAM, 2015. S. 147-158.

Chęcińska, Urszula. „Baśń końca nie ma”. Barwy świata baśni. Red. U. Chęcińska. Szczecin: Wydawnictwo Naukowe Uniwersytetu Szczecińskiego, 2003. S. 449-451.

Cichocka Tatiana, Miller Katarzyna. Bajki rozebrane. Łódź: Wydawnictwo JK, 2008.

Ciesielska, Adriana. „Typy waloryzacji światopoglądowej a struktura baśni”. Baśń we wspótczesnej kulturze. T. 1. Niewyczerpana moc baśni: literatura - sztuka - kultura masowa. Red. K. Ćwiklak. Poznań: Wydawnictwo UAM, 2014. S. 35-48.

Czabanowska-Wróbel, Anna. Baśń w literaturze Młodej Polski. Kraków: Universitas, 1996.

Ćwiklak, Kornelia. „Zaproszenie do baśni (drugie)”. Baśń we wspótczesnej kulturze. T. 2. Królestwo człowiecze: edukacja - psychoanaliza - arteterapia. Red. K. Ćwiklak. Poznań: Wydawnictwo UAM, 2015. S. 7-12.

Deszcz, Justyna. „Baśń dawniej i dziś. W kręgu teorii Jacka Zipesa”. Literatura Ludowa 4-5 (1998). S. 89-94. 
Dundes, Alan. "Bruno Bettelheim's Uses of Enchantment and Abuses of Scholarship”. Journal of American Folklore 104 (1991). S. 74-83.

Dundes, Alan. Parsing Through Customs: Essays by a Freudian Folklorist. Madison: University of Wisconsin Press, 1987.

Estés, Clarissa Pinkola. Biegnaca z wilkami. Archetyp Dzikiej Kobiety w mitach i legendach. Przeł. Agnieszka Cioch. Poznań: Zysk i S-ka, 2001.

Filipowska, Olga. „Sezon na czerwień. Rzecz o Czerwonym Kapturku XXI wieku”. Bajkowe inspiracje literaturoznawców i kulturoznawców. T. 2. Red. M. Zaorska, A. Grabowski. Olsztyn: Katedra UNESCO Uniwersytetu Warmińsko-Mazurskiego w Olsztynie, 2012. S. 87-100.

Gajownik, Sylwia. „Ksiażki to nie tylko kartki oprawne w tekturę lub płótno - o bajkach terapeutycznych Marii Molickiej". Bajkowe inspiracje jezzykoznawców, pedagogów i psychologów. T. 3. Red. A. Grabowski, M. Zaorska. Olsztyn: Katedra UNESCO Uniwersytetu Warmińsko-Mazurskiego w Olsztynie, 2012. S. 54-65.

Graban-Pomirska, Monika. „Mała dziewczynka we współczesnej baśni literackiej”. W poszukiwaniu matej dziewczynki. Red. I. Kowalczyk, E. Zierkiewicz. Poznań: Stowarzyszenie Kobiet „Konsola”, 2003. S. 105-112.

Grodzki, Bogusław. Leśmianowska baśń nowoczesna. O „Przygodach Sindbada Żeglarza" Bolesława Leśmiana. Lublin: Wydawnictwo UMCS, 2012.

Helman, Alicja. „Baśń w świecie filmu”. Kulturowe konteksty baśni. T. 1. Rozigrana córa mitu. Red. G. Leszczyński. Poznań: Centrum Sztuki Dziecka, 2005. S. 109-120.

Jolles, André. „Proste formy. Baśń”. Przeł. Ryszard Handke. Przegląd Humanistyczny 5 (1965). S. 65-84. Joosen, Vanessa. Critical and Creative Perspectives on Fairy Tales. An Intertextual Dialogue between Fairy-Tale Scholarships and Postmodern Retellings. Detroit: Wayne State University Press, 2011.

Jung, Carl Gustav. Archetypy i symbole: pisma wybrane. Przeł. Jerzy Prokopiuk. Warszawa: Czytelnik, 1976. Kalarus, Oskar. „Królewna Śnieżka kontra postmodernizm. Na podstawie twórczości Donalda Barthelemego, Andrzeja Sapkowskiego i Kaori Yuki". Baśn we wspótczesnej kulturze. T. 1. Niewyczerpana moc baśni: literatura - sztuka - kultura masowa. Red. K. Ćwiklak. Poznań: Wydawnictwo UAM, 2014. S. 297-308.

Karasińska, Marta. „Sam na sam. O samotności bohatera baśni magicznej”. Kulturowe konteksty baśni. T. 2. W poszukiwaniu straconego królestwa. Red. G. Leszczyński. Poznań: Centrum Sztuki Dziecka, 2006. S. 163-175.

Karaś, Marlena. „Baśń jako narzędzie biblioterapii w pracy rewalidacyjnej z dziećmi upośledzonymi w stopniu umiarkowanym lub znacznym". Baśń we wspótczesnej kulturze. T. 2. Królestwo człowiecze: edukacja - psychoanaliza - arteterapia. Red. K. Ćwiklak. Poznań: Wydawnictwo UAM, 2015. S. 195-200.

Kasjan, Jan Mirosław. Usta i pióro. Studia o literaturze ustnej i pisanej. Toruń: Wydawnictwo UMK, 1994.

Knapek, Olga. „Nieświadome nie zna czasu. O ponadczasowości”. Baśń we wspótczesnej kulturze. T. 1. Niewyczerpana moc baśni: literatura - sztuka - kultura masowa. Red. K. Ćwiklak. Poznań: Wydawnictwo UAM, 2014. S. 321-332.

Knapek, Ryszard. „To tylko bajka. Propp i polityka”. Bajkowe inspiracje literaturoznawców i kulturoznawców. T. 2. Red. M. Zaorska, A. Grabowski. Olsztyn: Katedra UNESCO Uniwersytetu Warmińsko-Mazurskiego w Olsztynie, 2012. S. 160-175. 
Kostecka, Weronika. Baśń postmodernistyczna: przeobrażenia gatunku. Intertekstualne gry z tradycją literacką. Warszawa: Wydawnictwo SBP, 2014.

Kubicki, Roman. „Koniec pewnego świata, czyli o baśni opowiadanej w chwilach tryumfu i zgonu”. Kulturowe konteksty baśni. T. 2. W poszukiwaniu straconego królestwa. Red. G. Leszczyński. Poznań: Centrum Sztuki Dziecka, 2006. S. 15-26.

Kwiek, Jadwiga. „Baśniowość w kulturze mediów elektronicznych”. Kulturowe konteksty baśni. T. 2. W poszukiwaniu straconego królestwa. Red. G. Leszczyński. Poznań: Centrum Sztuki Dziecka, 2006. S. 123-142.

Lasoń-Kochańska, Grażyna. „Dziewczynka, macocha, czarownica. Obraz kobiety w baśni”. Literatura Ludowa 4-5 (2011). S. 15-26.

Lasoń-Kochańska, Grażyna. „Kobieta w baśniach Hansa Christiana Andersena”. Bajkowe inspiracje językoznawców, pedagogów i psychologów. T. 3. Red. A. Grabowski, M. Zaorska. Olsztyn: Katedra UNESCO Uniwersytetu Warmińsko-Mazurskiego w Olsztynie, 2012. S. 89-103.

Leszczyński, Grzegorz. „Baśń jako matryca doświadczeń egzystencjalnych”. Kulturowe konteksty baśni. T. 1. Rozigrana córa mitu. Red. G. Leszczyński. Poznań: Centrum Sztuki Dziecka, 2005. S. 68-93.

Leszczyński, Grzegorz. „Baśń: rytuał przejścia (rite de passage). Kulturowe konteksty baśni. T. 2. W poszukiwaniu straconego królestwa. Red. G. Leszczyński. Poznań: Centrum Sztuki Dziecka, 2006. S. 41-68.

Lis-Kujawski, Andrzej. „Kim była Królowa Śniegu?”. Bajkowe inspiracje językoznawców, pedagogów i psychologów. T. 3. Red. A. Grabowski, M. Zaorska. Olsztyn: Katedra UNESCO Uniwersytetu Warmińsko-Mazurskiego w Olsztynie, 2012. S. 104-109.

Lüthi, Max. „Cechy narracji w bajce ludowej”. Przeł. Jan Mirosław Kasjan. Literatura Ludowa 2 (1982a). S. 63-69.

Lüthi, Max. „Style gatunkowe”. Przeł. Krystyna Krzemieniowa. Pamiętnik Literacki 1 (1973). S. 283-292.

Lüthi, Max. "Zabójca smoka. O stylu bajki”. Przeł. Jan Mirosław Kasjan. Literatura Ludowa 3 (1982b). S. 36-43.

Ługowska, Jolanta. „«Kopciuszek to ja! » W kręgu zagadnień baśniowej kompensacji”. Baśń we wspótczesnej kulturze. T. 1. Niewyczerpana moc baśni: literatura - sztuka - kultura masowa. Red. K. Ćwiklak. Poznań: Wydawnictwo UAM, 2014. S. 83-98.

Ługowska, Jolanta. „Słowo wstępne”. Baśnie nasze wspótczesne. Red. J. Ługowska. Wrocław: Polskie Towarzystwo Ludoznawcze, 2006a. S. 5-10.

Ługowska, Jolanta. W Fantazjanie i gdzie indziej. Szkice o baśni literackiej. Wrocław: Polskie Towarzystwo Ludoznawcze: Uniwersytet Wrocławski, 2006b.

Mochocki, Michał. „Współczesne oblicze baśni: narracyjne gry fabularne”. Barwy świata baśni. Red. U. Chęcińska. Szczecin: Wydawnictwo Naukowe Uniwersytetu Szczecińskiego, 2003. S. 185-192.

Mojkowska, Aleksandra. Max Lüthi jako bajkoznawca. Wrocław: Polskie Towarzystwo Ludoznawcze: Uniwersytet Wrocławski, 2006.

Molicka, Maria. „Psychologiczne aspekty aksjologii baśni”. Kulturowe konteksty baśni. T. 2. W poszukiwaniu straconego królestwa. Red. G. Leszczyński. Poznań: Centrum Sztuki Dziecka, 2006. S. 110-122.

Molicka, Maria. Biblioterapia i bajkoterapia. Rola literatury w procesie zmiany rozumienia świata społecznego i siebie. Poznań: Media Rodzina, 2011. 
Nowotniak, Justyna. „Świat bez baśni - kilka impresji o współczesnej szkole”. Barwy świata baśni. Red. U. Chęcińska. Szczecin: Wydawnictwo Naukowe Uniwersytetu Szczecińskiego, 2003. S. 349-357.

Paturej-Grandyberg, Jagoda. „Nowi bohaterowie starych opowieści, czyli postmodernistyczne transformacje bajek w wybranych tekstach Nataszy Goerke”. Bajkowe inspiracje literaturoznawców i kulturoznawców. T. 2. Red. M. Zaorska, A. Grabowski. Olsztyn: Katedra UNESCO Uniwersytetu Warmińsko-Mazurskiego w Olsztynie, 2012. S. 246-252.

Péju, Pierre. Dziewczynka w baśniowym lesie. O poetykę baśni: w odpowiedzi na interpretacje psychoanalityczne i formalistyczne. Przeł. Magdalena Pluta. Warszawa: Sic!, 2008.

Pieciul-Karmińska, Eliza. „Słowo od Tłumaczki”. Grimm Wilhelm, Grimm Jakub. Baśnie dla dzieci i domu. T. 2. Przeł. Eliza Pieciul-Karmińska. Poznań: Media Rodzina, 2010. S. 443-484.

Pilińska, Anna. „Opowiadania Vladimira Nabokova jako literackie baśnie dla dorosłych”. Baśn we wspótczesnej kulturze. T. 1. Niewyczerpana moc baśni: literatura - sztuka - kultura masowa. Red. K. Ćwiklak. Poznań: Wydawnictwo UAM, 2014. S. 287-296.

Propp, Vladimir. Nie tylko bajka. Przeł. Danuta Ulicka. Warszawa: PWN, 2000.

Ratajczyk, Małgorzata. „Między bajką a baśnią”. Baśń we wspótczesnej kulturze. T. 1. Niewyczerpana moc baśni: literatura - sztuka - kultura masowa. Red. K. Ćwiklak. Poznań: Wydawnictwo UAM, 2014. S. 117-132.

Rose, Jacqueline. The Case of Peter Pan or the Impossibility of Children's Literature. Filadelfia: University of Pennsylvania Press, 1993.

Sadowska, Monika. „Pocałunek zabija równie często jak leczy, czyli o Siostrze Małgorzaty Saramonowicz”. Baśn we wspótczesnej kulturze. T. 1. Niewyczerpana moc baśni: literatura - sztuka - kultura masowa. Red. K. Ćwiklak. Poznań: Wydawnictwo UAM, 2014. S. 261-274.

Serafin, Ewa. „Struktura symboliczna baśni Janiny Porazińskiej Zaczarowana w żabkę”. Bajkowe inspiracje literaturoznawców i kulturoznawców. T. 2. Red. M. Zaorska, A. Grabowski. Olsztyn: Katedra UNESCO Uniwersytetu Warmińsko-Mazurskiego w Olsztynie, 2012. S. 267-286.

Skorupska-Raczyńska, Elżbieta. „Barwy w językowej kreacji świata baśni (na wybranych przykładach). Barwy świata baśni. Red. U. Chęcińska. Szczecin: Wydawnictwo Naukowe Uniwersytetu Szczecińskiego, 2003. S. 83-96.

Skrendo, Andrzej. „Kanon i lektura”. Kanon i obrzeża. Red. I. Iwasiów, T. Czerska. Kraków: Universitas, 2005.

Sławińska, Małgorzata. „Bajka jako źródło wiedzy interpretacyjnej dziecka - od fikcji do prawdziwego życia". Bajkowe inspiracje językoznawców, pedagogów i psychologów. T. 3. Red. A. Grabowski, M. Zaorska. Olsztyn: Katedra UNESCO Uniwersytetu Warmińsko-Mazurskiego w Olsztynie, 2012. S. 208-222.

Stefaniak, Beata. „Labirynt fauna - baśń ocalona, baśń ocalająca”. Baśn we wspótczesnej kulturze. T. 1. Niewyczerpana moc baśni: literatura - sztuka - kultura masowa. Red. K. Ćwiklak. Poznań: Wydawnictwo UAM, 2014. S. 311-320.

Stein, Sharman. "Bettelheim Accused Of Plagiarizing Book". Chicago Tribune, Feb 7 (1991). Web. 29.03.2016. <http://articles.chicagotribune.com/1991-02-07/news/9101110905_1_dundes-article-sonia-shankman-orthogenic-school-bruno-bettelheim>

Suchowierska Agnieszka, Eichelberger Wojciech. Królewicz Śnieżek: baśniowe stereotypy ptci - bajki na opak. Warszawa: Wydawnictwo Czarna Owca, 2012. 
Szabłowska-Zaremba, Monika. „Bajki Isaaca Bashevisa Singera - zaproszenie ucznia do spotkania z wielokulturowością". Baśń we wspótczesnej kulturze. T. 2. Królestwo człowiecze: edukacja - psychoanaliza - arteterapia. Red. K. Ćwiklak. Poznań: Wydawnictwo UAM, 2015. S. 107-122.

Świerczyńska-Jelonek, Danuta. „Baśniowość i antropologiczna wrażliwość współczesnej obyczajowej i psychologicznej lietratury młodzieżowej". Sztuka dla dziecka. Tradycja we wspótczesności. Red. G. Leszczyński, współpraca H. Gawrońska. Poznań: Centrum Sztuki Dziecka, 2011. S. 153-176.

Tatar, Maria. Enchanted Hunters. The Power of Stories in Childhood. New York, London: W.W. Norton\&Company, 2009.

Tatar, Maria. The Hard Facts of the Grimms' Fairy Tales. Princeton: Princeton University Press, 1987.

Wais, Jadwiga. Ścieżki baśni. Symboliczne wędrówki do wnętrza duszy. Warszawa: ENETEIA, 2007.

Waksmund, Ryszard. „Baśń dla młodzieży jako problem genologiczny i pedagogiczny (z perspektywy historycznoliterackiej)". Barwy świata baśni. Red. U. Chęcińska. Szczecin: Wydawnictwo Naukowe Uniwersytetu Szczecińskiego, 2003. S. 71-81.

Waksmund, Ryszard. Od literatury dla dzieci do literatury dziecięcej. (Tematy - gatunki - konteksty). Wrocław: Wydaw. Uniwersytetu Wrocławskiego, 2000.

Węgrodzka, Jadwiga. „Baśnie w (kon)tekście osiemnastowiecznym: Sarah Fielding i jej Guwernantka”. Bajkowe inspiracje literaturoznawców i kulturoznawców. T. 2. Red. M. Zaorska, A. Grabowski. Olsztyn: Katedra UNESCO Uniwersytetu Warmińsko-Mazurskiego w Olsztynie, 2012. S.306-319.

Wlazło, Marcin. „Baśń jako podstawa dialogu literackiego i terapeutycznego w edukacji specjalnej i integracyjnej". Barwy świata baśni. Red. U. Chęcińska. Szczecin: Wydawnictwo Naukowe Uniwersytetu Szczecińskiego, 2003. S. 309-320.

Wojciechowska, Dorota. „Baśniowy elementarz Tadeusza Konwickiego”. Baśnie nasze wspótczesne. Red. J. Ługowska. Wrocław: Polskie Towarzystwo Ludoznawcze, Uniwersytet Wrocławski, 2006. S. 115-150.

Wojciechowska, Dorota. „Po co komu smutne baśnie - o problemach dziecięcej tanatologii”. Baśnie nasze wspótczesne. Red. J. Ługowska. Wrocław: Polskie Towarzystwo Ludoznawcze, Uniwersytet Wrocławski, 2006. S. 197-230.

Wojciechowska, Dorota. „Psychoterapeutyczne znaczenia baśni”. Barwy świata baśni. Red. U. Chęcińska. Szczecin: Wydawnictwo Naukowe Uniwersytetu Szczecińskiego, 2003. S. 301-308.

Zgrzywa, Agnieszka. „Baśń w prozie poety”. Baśń we wspótczesnej kulturze. T. 1. Niewyczerpana moc baśni: literatura - sztuka - kultura masowa. Red. K. Ćwiklak. Poznań: Wydawnictwo UAM, 2014. S. 197-210.

Ziolkowski, Jan. Fairy Tales from Before Fairy Tales: The Medieval Latin Past of Wonderful Lies. Ann Arbor: University of Michigan Press, 2007.

Zipes, Jack. Andersen. The Misunderstood Storyteller. Nowy Jork, Londyn: Routledge, 2005.

Zipes, Jack. Breaking the Magic Spell. Radical Theories of Folk and Fairy Tales. Revised and expanded edition. Lexington: University Press of Kentucky, 2002.

Zipes, Jack. Fairy tale as myth, myth as fairy tale. Lexington: University Press of Kentucky, 1994.

Zipes, Jack. When Dreams Came True. Classical Fairy Tales and Their Tradition. Wyd. 2. Nowy Jork, Londyn: Routledge, 2007.

Zipes, Jack. Why Fairy Tales Sticks. The Evolution and Relevance of a Genre. Nowy Jork, Londyn: Routledge, 2006. 